\title{
Facilitating the employment of people with mental health difficulties in Ireland
}

\author{
Margaret Tighe* and Caroline Murphy \\ Health Service Executive, Ireland. margaret.tighe@hse.ie \\ University of Limerick, Ireland.
}

\begin{abstract}
The promotion of practices supporting positive mental health at work is increasingly important on employers' agendas. However, within the HRM literature there is a relative dearth of research on how employers can facilitate reintegration into the workplace or first-time employment for employees with mental health issues. Publicly funded supports are emerging as a strategy that can provide targeted supports to both workers and employers. This paper aims to investigate the effectiveness of this approach by undertaking triadic research with employers, healthcare professionals, and workers using the service in the Irish context. We make recommendations regarding the enhancement of opportunities currently available to those with a mental health difficulty to return to and remain in employment. The paper contributes to our understanding of the nature of supports required to successfully facilitate employing or re-integrating those with a mental health disability or history of mental health problems into the workplace.
\end{abstract}

Keywords: Mental health; inclusion; supported employment

\section{INTRODUCTION}

Mental health has become a key societal concern in Ireland, as well as being increasingly prevalent on employers' agendas. Mental health issues have a significant impact on employee wellbeing and are a major contributor of longterm absence from work (CIPD, 2018). A report compiled by Mental Health Reform (2015) highlights that people of working age who have mental health difficulties are nine times more likely to be out of the workforce. Findings in the 2016 Census noted an increase in the numbers of people stating that they had a disability in all categories, with the largest increase of $29 \%$ in those with a psychological or emotional condition (CSO, 2017). While this study was undertaken prior to the COVID-19 pandemic, multiple indicators suggest that mental health concerns will increase as a result of the changes that occurred in 2020 (Beland et al., 2020). These findings add urgency to the need for research and practical supports for both employees and employers in the Irish context. To date, much of the research of relevance to employers focuses on preventative rather than restorative actions (Carroll et al., 2010; Henderson et al., 2013). While employers are encouraged to promote good mental health, there is a dearth of research on how they can facilitate reintegration into the workplace after a period of absence. Research in the area has mainly been conducted within the medical and health science field, rather than from a human resources viewpoint (Bilsker et al., 2004; De Lorenzo, 2013).

Hampson, et al. (2016) noted significant barriers identified by mental health service users in returning to employment. Non-clinical barriers include interpersonal barriers such as stigma and discrimination (Krupa, et al., 2009). The unemployment rate among those diagnosed with a mental health disability is disproportionately high in comparison with the general population (O'Day, et al., 2017; Watson, et al., 2015). Targeted and evidencedbased support for those with a mental health difficulty to return to the workforce has been cited as an unmet need for service users attending Mental Health Services in Ireland (Cullen, et al., 2017; Mental Health Reform, 2018). 
Efforts have therefore been put in place to address this need, focusing on linking employees with employment specialists who can support them in finding and sustaining employment. Employers play a crucial role in this. The aim of this paper is therefore to examine such an initiative in the Irish context. We explore from a multi-stakeholder perspective how to facilitate transitions to employment for this group in conjunction with publicly funded supports and employer cooperation. The paper contributes to our understanding of the factors that facilitate and inhibit labour force participation for individuals with mental health difficulties and how these can be overcome. Our contribution is unique, in that we utilise the views not only of a matched sample of employers and employees, but also those of mental health professionals working with those individuals to form a triadic understanding of how employment can be attained and sustained. Until now, the literature has focused mainly on employees and employers, but has rarely integrated the views of mental health professionals from multidisciplinary teams (MDT), who support employment integration through their role.

\section{Health benefits of employment}

The therapeutic importance of suitable employment and its ability to enhance a person's health and wellbeing is widely noted in research (Drake, et al., 2012; Khalema and Shankar, 2014; Prior, et al., 2013). Jahoda's latent deprivation theory (1982) posits that employment provides people with structure, purpose, social connectedness, identity and activity, with these latent benefits of employment contributing to psychological wellbeing (Batinic, et al., 2010).

Suitable employment has many advantages for individuals with mental health difficulties, including its welldocumented association with reductions in outpatient psychiatric appointments and improved quality of life (Amnesty International, 2013; Luciano, et al., 2014). The importance of engaging in a meaningful occupation is central to promoting social inclusion, increasing a person's self-esteem and improving income levels of those with a mental health disability (Drake and Bond, 2011; Knapp, et al., 2014; Luciano, et al., 2014; Meuser, et al., 2016) with returning to employment cited as a key factor for a person with a mental health disability in their recovery journey (Cullen, et al., 2017; Prior, et al., 2013).

\section{Challenges of labour market participation}

In Ireland, a person attending a secondary or specialist mental health service is deemed to have a severe and enduring mental illness (Mental Health Reform, 2018). Symptoms may begin early in a persons' life and persist for decades, affecting cognitive and social functioning, which in turn impacts negatively on educational status, housing, physical health and of course employment options (Hodgson, et al., 2011). Early onset of mental health disability can act as a barrier to school completion and can therefore limit a person's ability to obtain suitable employment, gain financial security and reduce dependence on welfare (Leach and Butterworth, 2012; Mojtabai, et al., 2015). Clients with a mental health disability often rely on positions in gardening, or in food or janitorial services. These positions often provide fewer opportunities for career advancement and financial security (Krupa, et al., 2009). For those with existing qualification or skills, or for those who simply want more permanent work, this can represent a form of underemployment, which in itself is expected to contribute to negative consequences for the health and wellbeing of individuals (Cassidy and Wright 2008). After re-employment, workers also tend to find jobs of lower quality than those previously held (McKee and Harvey 2011).

Mental illness can have a severe and negative impact on many life domains, leading to the need for multiple supports from the mental health treatment teams (Drake, et al., 2012). Cognitive functioning may be affected by a mental health illness, particularly in the areas of memory, concentration, regulation of emotions and perceptions of reality. The side-effects of medication, such as fatigue, drowsiness and weight gain, can compound this, making it difficult for those affected to function effectively in the work environment (Khalema and Shankar, 2014). These illnesses produce severe and debilitating symptoms for clients, often requiring admissions to psychiatric hospitals and the need for long-term care with mental health treatment teams (Hodgson, et al., 2011). Another important concern for clients who are returning to employment is the effect this may have on a person's social welfare entitlement and other secondary benefits they may be receiving (O'Day, et al., 2017). A fear of losing a social welfare payment can act as a disincentive to returning to employment for those with a mental health illness or may act as a constraint to them returning to full-time employment, causing them to seek part-time hours as a way of retaining welfare payments (Krupa, et al., 2009; O'Day, et al., 2017). Research suggests that earnings 
from supported employment are typically low and that this is strongly associated with disincentives in the welfare payment system for those with a disability to return to employment (Campbell, et al., 2011). Difficulties encountered by clients when returning to a welfare payment if a job placement does not work out can also act as a constraint to returning to employment (Bond and Drake, 2014), leading to a 'benefit trap' situation (Boardman and Rinaldi, 2013).

\section{Public policy support services for mental health clients in Ireland}

The A Vision for Change (2006) strategy document provides a framework for the delivery of mental health services in Ireland. It recommended that services should be put in place to facilitate meaningful employment with the development of support services and coordination between training and vocational agencies (Health Service Executive, 2006). In response, a pilot project entitled Integrating Employment and Mental Health Supports (IEMHS) was trialled from 2015-2017. As part of this, the Health Service Executive (HSE), Department of Employment Affairs and Social Protection, and Mental Health Reform worked together in implementing the individual placement and support (IPS) model of supported employment. This pilot involved supporting those with severe and enduring mental health difficulties to return to paid competitive employment in the West, South, North-East and Northern regions. Findings published by Mental Health Reform, following completion of the project, revealed that a third of participants were successful in obtaining paid work, while almost a fifth of participants went on to further education or training. Five per cent moved from supported accommodation to independent living during the timeline of the project, highlighting the positive social outcomes, even where clients where not successful in obtaining paid, competitive employment (Mental Health Reform, 2018).

\section{Individual placement and support (IPS) model}

The IPS model is currently the most empirically researched and successful supported employment model internationally developed for specifically supporting people with severe and enduring mental health difficulties and their employers or potential employers (Meuser, et al., 2016; O'Day, et al., 2017). The IPS model emphasises a 'place and then train' approach, rather than the traditional model of vocational rehabilitation that favours a 'train and then place' approach (Drake, 1998). A key feature of IPS supported employment is that it emphasises open competitive employment as a primary goal. This is in contrast with other vocational rehabilitation services that aim to employ people in sheltered workshops. McAnaney and Wynne (2017) argue that such methods do not serve the varying and complex needs that a person may have at their different life stages. The IPS model's 'place and train' approach is to help people secure a job in line with the individual's preferences, as quickly as possible, and then support them in it, in contrast with the lengthy pre-employment training/preparation and prerequisite for the person to be 'job ready' to which other supported employment approaches adhere. A policy of zero exclusion is applied in considering factors such as job readiness, education/training and current physical health (Campbell, et al., 2010). If a client states that they want to return to employment, an employment specialist who is a member of the MDT assists them in this. Individualised support is provided to both the employer and client, as required, once a job placement is secured.

\section{Employer-related issues}

The concerns of employers regarding employing a person with a mental health illness include issues pertaining to trust, lack of practical capabilities and frequent absenteeism (Essen, 2012; Drake, et al., 2012; 2014). Research suggests that employers may view employing a person with a mental health disability as an 'act of charity' and not see the potential the person has to offer in the workplace (Krupa, et al., 2009). Research also suggests that the way in which mental health illness is reported in the media also has a significant negative impact on employers' attitudes to employing a person with a mental health difficulty (McClelland, et al., 2000), since they are concerned about potential violence and other undesirable traits and behaviours associated with the illness (Gaffey and Evans, 2016). This can be improved by creating better awareness through education and by supporting inclusion and diversity in the workplace (Biggs, et al., 2010; Krupa, et al., 2009). In Ireland, programmes such as the See Change Programme have been introduced to address the stigma of mental health in the workplace. Research by See Change in Ireland revealed that $46 \%$ of people under the age of 35 would conceal a mental health difficulty, with while only $66 \%$ of people were found to be willing to work with someone with a mental health difficulty (See Change, 2017).

Employers frequently state the need to able to access timely and appropriate advice when employing a person with a mental health difficulty (Biggs, et al., 2010), since guidance regarding employing a person with a mental health disability is lacking in comparison to employing a person with a physical disability (Krupa, et al., 2009). Irish 
equality legislation places the responsibility not to discriminate against people with a mental health disability under disability grounds firmly on the employer. This legislation also includes the responsibility of the employer to provide reasonable accommodations to the person, where appropriate. However, the legislation poses a challenge for employers, given its limited description of a reasonable workplace adaption for those with a mental health difficulty, combined with little empirical data available pertaining to suitable adaptions (Villotti, et al., 2017). Most workplace accommodations for the mental health client, while being unique to the individual, are actually low in cost, although with limited knowledge, a perception can exist that the costs are greater.

Research suggests that those with a mental health illness are highly disinclined to disclose this to an employer when seeking employment at either the written application stage or the interview stage, citing fears of stigmatisation and/or discrimination (Donnelly, 2017). Disclosing a mental health illness to an employer carries with it both risks and benefits. Benefits may include help and support from colleagues and reasonable accommodations such as flexible working hours and job-sharing possibilities (Biggs, et al., 2010; Rusch, et al., 2017).

Mental health tends to be an 'invisible' disability (Shefer, et al., 2016; Drake, et al., 2012). A physical illness or disability is usually more observable to others. This 'invisibility' can raise questions regarding the legitimacy of the mental health illness. Employees with a mental health illness may be viewed by colleagues as receiving special treatment and shirking responsibility in the workplace (Krupa, et al., 2009). Supervisors and line mangers provide feedback to employees regarding performance and addressing matters such as poor time keeping, poor job performance and personal appearance. However, research suggests that supervisors and line managers may be uncomfortable addressing such matters with employees who have disclosed a mental health difficulty, feeling that it may be inappropriate or best not to do so, as they can see no clear way how these matters may be resolved (Bell, et al., 2007).

\section{METHODOLOGY}

An interpretivist method was adopted in this research by means of a social constructionism approach, in order to gain an understanding of the individual participants' opinions. A qualitative approach was adopted to collect, analyse and interpret the data, which were obtained by adopting a triangulation approach (Edmondson and McManus, 2007) and from the following viewpoints. The first was service users who had availed of the IPS Supported Employment Project. A randomly selected convenience sample of six service users, four males and two females, were interviewed with a mean age of 41 years. Five had a previous work history but all were currently unemployed, and all were deemed to have a severe and enduring mental health difficulty.

The second group of participants were members of the MDT working within the Rehab and Recovery Team. A randomly selected convenience sample of eight MDT members were interviewed from various disciplines, which included nursing, nurse management, psychology, social work and occupational therapy. All MDT members were involved with the day-to-day care of the service users involved in the study.

Finally, employers who had provided vocational opportunities to service users during the pilot of the supported employment programme from 2015-2017 were identified. A random sample of eight of these employers were interviewed. Businesses were small-to-medium-size enterprises (SMEs) employing fewer than 12 people, both part and full time, with four being described as retail outlets and the remainder in construction, services, media and funded charitable organisations. Employees had made a disclosure of a mental health difficulty to all employers and each had put in place reasonable accommodations to some degree or had availed of on-the-job training provided by an employment specialist in their organisation.

This selection was representative of the total samples available, in line with best practice, when choosing research samples (Easterby-Smith, et al., 2015). All researchers have a duty of care to all research participants (Cassell, 1982; Bell and Bryman, 2007). However, additional measures and extra considerations are necessary when the research participants are from a vulnerable population, such as those with severe and enduring mental health difficulties (McCann and Clark, 2005). Ethical approval for this research was granted by the HSE local ethics committee and the author obtained informed written consent from all service user participants, in keeping with best practice for ethical research (Bell and Bryman, 2007; Easterby-Smith, et al., 2015).

\section{Data collection and analysis}

Validity in qualitative research is achieved through the appropriate selection and questioning of participants, and 
Table 1. Participant Profile Overview

\begin{tabular}{|c|c|c|c|c|c|c|}
\hline \multicolumn{2}{|c|}{$\begin{array}{c}\text { Employer Participant } \\
\text { Profile }\end{array}$} & \multicolumn{5}{|c|}{ Type of vocational role offered to Service Users } \\
\hline \multirow{2}{*}{$\begin{array}{c}\text { ID } \\
\text { EMP 1 }\end{array}$} & \multirow{2}{*}{$\begin{array}{c}\begin{array}{c}\text { Type of } \\
\text { Business }\end{array} \\
\text { Funded Charitable } \\
\text { Organisation }\end{array}$} & \multirow[t]{2}{*}{$\begin{array}{l}\text { Voluntary } \\
\text { Role }\end{array}$} & \multirow{2}{*}{$\begin{array}{c}\begin{array}{c}\text { Work } \\
\text { Experience }\end{array} \\
X\end{array}$} & \multirow[t]{2}{*}{ Paid employment } & \multicolumn{2}{|c|}{$\begin{array}{c}\text { Length of Time Service Users } \\
\text { engaged with Employer and } \\
\text { Roles }\end{array}$} \\
\hline & & & & & $\begin{array}{l}1 \times \text { Service User } \\
4 \text { Weeks } 2 \times \text { days } \\
\text { per week }\end{array}$ & $\begin{array}{l}\text { Work Experience } \\
\text { in Clerical } \\
\text { role, minimum } \\
\text { completion level }\end{array}$ \\
\hline EMP 2 & Retail & & $x$ & & $\begin{array}{l}1 \times \text { Service User } \\
8 \text { Weeks } \\
2 \times \text { days per week }\end{array}$ & $\begin{array}{c}\text { Completed } \\
\text { Stockroom duties }\end{array}$ \\
\hline EMP 3 & $\begin{array}{l}\text { Funded Charitable } \\
\text { Organisation }\end{array}$ & & $x$ & & $\begin{array}{c}2 \times \text { Service Users } \\
4 \text { Weeks } 1 \times \text { day per } \\
\text { week } \\
4 \text { Weeks } 2 \times \text { days } \\
\text { per week }\end{array}$ & $\begin{array}{l}\text { Both Clerical } \\
\text { Roles } \\
\text { Completed } \\
\text { Incomplete } \\
\text { Only } 2 \text { days } \\
\text { completed }\end{array}$ \\
\hline EMP 4 & Retail & & $x$ & & $\begin{array}{c}2 \times \text { Service Users } \\
3 \text { months } \\
2 \times \text { days per week } \\
3 \text { weeks } \\
1 \times \text { day per week }\end{array}$ & $\begin{array}{l}\text { Completed } \\
\text { Stockroom } \\
\text { Shop floor }\end{array}$ \\
\hline EMP 5 & $\begin{array}{l}\text { Construction and } \\
\text { Service Industry }\end{array}$ & & & $x$ & $\begin{array}{c}8 \times \text { months } \\
1 \times \text { day per week }\end{array}$ & $\begin{array}{l}\text { Ongoing paid } \\
\text { employment } \\
\text { Office Cleaner }\end{array}$ \\
\hline EMP 6 & Retail & $x$ & & & $\begin{array}{c}14 \text { months } \\
1 \times \text { day per week }\end{array}$ & $\begin{array}{l}\text { Ongoing } \\
\text { Shop Floor }\end{array}$ \\
\hline EMP 7 & Retail & $x$ & & & $\begin{array}{c}2 \text { years } \\
1 \times \text { day per week }\end{array}$ & $\begin{array}{l}\text { Ongoing } \\
\text { Shop Floor }\end{array}$ \\
\hline EMP 8 & Media & & $x$ & & $\begin{array}{c}16 \text { weeks } \\
1 \text { day per week }\end{array}$ & $\begin{array}{c}\text { Ongoing } \\
\text { General assistant }\end{array}$ \\
\hline \multicolumn{2}{|c|}{$\begin{array}{c}\text { Multi-Disciplinary Team } \\
\text { Profile }\end{array}$} & \multicolumn{3}{|c|}{ Discipline } & & \\
\hline ID & Nursing & $\begin{array}{l}\text { Social } \\
\text { Work }\end{array}$ & Nurse & lanagement & Psychology & $\begin{array}{c}\text { Occupational } \\
\text { Therapy }\end{array}$ \\
\hline MDT 1 & & & & & & $x$ \\
\hline MDT 2 & & & & $x$ & & \\
\hline MDT 3 & & & & & $x$ & \\
\hline MDT 4 & & & & $x$ & & \\
\hline MDT 5 & $x$ & & & & & \\
\hline MDT 6 & & $x$ & & & & \\
\hline MDT 7 & $x$ & & & & & \\
\hline MDT 8 & & & & & & $x$ \\
\hline
\end{tabular}




\begin{tabular}{|c|c|c|c|c|c|c|}
\hline \multirow[b]{2}{*}{ ID } & \multicolumn{2}{|c|}{ Service User Participant Profile } & \multicolumn{2}{|c|}{$\begin{array}{c}\text { Vocational activities } \\
\text { engaged in }\end{array}$} & \multicolumn{2}{|c|}{ Background Details } \\
\hline & $\begin{array}{c}\text { Paid } \\
\text { Employment }\end{array}$ & Voluntary Role & $\begin{array}{l}\text { Upskilling/ } \\
\text { Re-training }\end{array}$ & $\begin{array}{c}\text { Work } \\
\text { Experiences }\end{array}$ & $\begin{array}{l}\text { Length of time } \\
\text { unemployed }\end{array}$ & $\begin{array}{l}\text { Multiple } \\
\text { supports }\end{array}$ \\
\hline SU 1 & & & & $x$ & $\begin{array}{l}12 \text { years since last } \\
\text { paid employment }\end{array}$ & $\begin{array}{l}\text { Psychology } \\
\text { Nursing }\end{array}$ \\
\hline SU 2 & $x$ & $x$ & $x$ & $x$ & $\begin{array}{c}20 \text { years since last } \\
\text { paid employment } \\
\text { Attending Sheltered } \\
\text { workshop }\end{array}$ & $\begin{array}{c}\text { Peer Support } \\
\text { Worker } \\
\text { Occupational } \\
\text { Therapy } \\
\text { Health Care } \\
\text { Assistant }\end{array}$ \\
\hline SU 3 & & & $x$ & $x$ & $\begin{array}{l}14 \text { years since last } \\
\text { paid employment }\end{array}$ & $\begin{array}{c}\text { Nursing Staff } \\
\text { Social Worker } \\
\text { Occupational } \\
\text { Therapy } \\
\text { Peer Support } \\
\text { Worker }\end{array}$ \\
\hline SU 4 & & $x$ & & & $\begin{array}{l}12 \text { years since paid } \\
\text { employment } \\
\text { Currently attending } \\
\text { Sheltered workshop }\end{array}$ & $\begin{array}{l}\text { Nursing Staff } \\
\text { Occupational } \\
\text { Therapy }\end{array}$ \\
\hline SU 5 & & & $x$ & & $\begin{array}{l}\text { No previous } \\
\text { employment history } \\
\text { Currently attending } \\
\text { Sheltered workshop }\end{array}$ & $\begin{array}{l}\text { Nursing } \\
\text { Health Care } \\
\text { Assistant } \\
\text { Peer Support } \\
\text { Worker } \\
\text { Occupational } \\
\text { Therapy }\end{array}$ \\
\hline SU 6 & & $x$ & & & $\begin{array}{l}40 \text { years approx. } \\
\text { Sheltered workshops } \\
\text { only since then }\end{array}$ & $\begin{array}{l}\text { Nursing } \\
\text { Health Care } \\
\text { Assistant }\end{array}$ \\
\hline
\end{tabular}

through scrupulous data analysis and reporting on the findings (Fischer, 2006). A total of 22 interviews were conducted during this research project, comprising both structured and semi-structured interviews. Structured interviews were conducted with service users and MDT members, to prevent data from being compromised by the corresponding author's position as an employment specialist in the rehab and recovery unit (Schultze and Avital, 2011). The decision to use structured interviews was justified by research to be the most appropriate method of data collection, to reduce interviewer bias and to yield the most appropriate and actionable results (Wilson, 2014). Research also suggests that structured interviews may also be more suited to individuals who have severe and enduring mental health difficulties, as they may not be able to interpret abstract questions (McCann and Clark, 2005).

Semi-structured interviews were conducted with local employers, who provided vocational opportunities for service users who engaged with the IEMHS project. Semi-structured interviews were adopted to gain an understanding of employing a person with a mental health difficulty from the employer's perspective. Research suggests this to be a suitable data collection tool when behaviours cannot be observed directly (Wilson, 2014). Semi-structured interviews were chosen for this cohort of research participants due to the variety of business involved, the variety of roles in which participants engaged in, the varying lengths of time in which the service user and employer engaged with the project, and the different issues that may or may not have proved problematic.

Four themes identified in the literature (Table 2) were used to inform the interview questions. These themes related to the suitability of the IPS model of supported employment, cognitive and social functioning of clients, employment/vocational related issues and stigma surrounding mental health. The findings are also presented around these themes. 
Table 2. Summary of themes identified in the literature

\begin{tabular}{|c|c|c|}
\hline THEME & AUTHORS & DESCRIPTION \\
\hline $\begin{array}{c}\text { Suitability of Individual Placement and } \\
\text { Support (IPS) model of supported } \\
\text { employment }\end{array}$ & $\begin{array}{c}\text { (Essen, 2012) } \\
\text { (Drake \& Bond, 2011) } \\
\text { (Swanson, et al., 2014) } \\
\text { (Khalema \& Shankar, 2014) } \\
\text { (Hamilton, et al., 2013) } \\
\text { (Boardman \& Rinaldi, 2013) } \\
\text { (Krupa, et al., 2009) (Gaffey \& Evans, 2016) }\end{array}$ & $\begin{array}{c}\text { Costs involved in IPS implementation } \\
\text { Success measured only in terms of paid } \\
\text { competitive employment } \\
\text { Non-vocational outcomes not measured } \\
\text { Lack of knowledge in mental health treatment } \\
\text { teams } \\
\text { Recovery based practices }\end{array}$ \\
\hline $\begin{array}{l}\text { Cognitive and Social functioning of the } \\
\text { mental health client }\end{array}$ & $\begin{array}{c}\text { (Drake, et al., 2012) } \\
\text { (Hodgson, et al., 2011) } \\
\text { (Khalema \& Shankar, 2014) } \\
\text { (Meuser, et al., 2016) } \\
\text { (Essen, 2012) } \\
\text { (Prior, et al., 2013) } \\
\text { (Mojtabai, et al., 2015) } \\
\text { (Krupa, et al., 2009) }\end{array}$ & $\begin{array}{c}\text { Clients low personal causation } \\
\text { Side effects of medication - fatigue, } \\
\text { concentration, weight gain } \\
\text { Physical health issues and co-morbidity } \\
\text { Educational attainments of clients }\end{array}$ \\
\hline Employment/Nocational related issues & $\begin{array}{c}\text { (Meuser, et al., 2016) } \\
\text { (Pearson, et al., 2012) } \\
\text { (O'Day, et al., 2017) } \\
\text { (Cullen, et al., 2017) } \\
\text { (Watson, et al., 2015) } \\
\text { (Prior, et al., 2013) } \\
\text { (Mental Health Reform, 2015) (Essen, 2012) } \\
\text { (Khalema \& Shankar, 2014) } \\
\text { (Batinic, et al., 2010) } \\
\text { (McClelland, et al., 2000) } \\
\text { (Boardman \& Rinaldi, 2013) } \\
\text { (Krupa, et al., 2009) } \\
\text { (Mental Health Reform, 2018) }\end{array}$ & $\begin{array}{l}\text { Lack of guidance for employers when employing } \\
\text { a person with a mental health difficulty } \\
\text { Social welfare system - the benefits trap } \\
\text { Lack of practical capabilities of clients } \\
\text { Health benefits of suitable employment } \\
\text { Vocational opportunities available }\end{array}$ \\
\hline Stigma surrounding mental health & $\begin{array}{c}\text { (Krupa, et al., 2009) } \\
\text { (Hampson, et al., 2016) } \\
\text { (Amnesty International, 2013) } \\
\text { (Holland, 2012) } \\
\text { (Gaffey \& Evans, 2016) } \\
\text { (Donnelly, 2017) } \\
\text { (Rusch, et al., 2017) }\end{array}$ & $\begin{array}{c}\text { Stigma } \\
\text { Discrimination } \\
\text { Media's portrayal of mental illness } \\
\text { Negative career consequences of disclosure }\end{array}$ \\
\hline
\end{tabular}

Questions relevant to these themes were formulated to gather data on similar topics, to provide a more coherent and thoughtful response from interviewees (Easterby-Smith, et al., 2015). Principles of good design in structured interviews was adhered to, in that one item was asked per question. All jargon was avoided, with simple expressions used, and leading questions were avoided (Easterby-Smith, et al., 2015). In the interviews with service users and MDT members, meaningful responses were encouraged with the use of open-ended questions such as, 'Can you describe any concerns that you may have regarding disclosure to employers that you have a mental health difficulty?' Some closed questions were also included in both the structured and semi-structured interviews. This was to allow for specific answers to be given to a limited range of responses. These questions related specifically to the suitability of the IPS model of supported employment in the Irish Mental Health Services. A thematic analysis technique was employed to disseminate the data obtained from the participants, using a systematic, rigorous, and auditable process, in line with best practice (Braun and Clarke, 2006).

\section{FINDINGS}

\section{Suitability of IPS model of supported employment}

The questions asked in this section focused on both the possibility and suitability of service users going straight into paid competitive employment, in line within the core IPS principle of adopting a 'place and then train' ethos for service users. Employer questions related to the capability of service users to return to paid competitive employment within their organisation or a similar organisation. The employers who were interviewed stated that of the nine service users collectively who had availed of vocational opportunities within their organisation or business, 
only three were capable of paid competitive employment. Employers stated that a further two service users were capable of some sort of employment but 'would need extra assistance and support'. The employers stated that in their opinion, four service users who availed of vocational opportunities within their organisations 'were not capable of any employment at that time'.

No MDT member suggested that service users should go straight back into paid employment, stating that work trial/work experience opportunities or education/retraining opportunities were preferable first options, with one participant stating: 'Most people who have been out of the workforce need to re-train or upskill not just those with a mental health issue"(MDT4).

Of the six service users interviewed, only two (SU1, SU2) stated that they wished to avail of paid competitive employment as a first step back into the workforce, with (SU2) stating: 'I would like to go back to work full time to be more independent' (SU2).

Availing of work experiences/work trial opportunities was the preferred choice for almost half of service users interviewed, as a first step back into the workforce, with one (SU6) stating, 'I wouldn't be fit to do that now,' referring to paid competitive employment, and another (SU3) stating, 'Competitive work would be difficult.'

\section{Cognitive and social functioning at work}

Employers were asked for their opinions on how the service users functioned in the workplace in comparison to other employees. Four employers highlighted the lack of training and current skillset as a major difficulty for service users in the workplace, with one stating: 'I do not have the time or manpower to sit beside them [service users] and guide them through every little aspect of the job' (EMP3).

Two employers highlighted the Service Users lack of energy in the workplace with comments such as: 'She is tired, exhausted and just not with it' (EMP7); 'very tired but I put that down to medication' (EMP1); and 'Four hours was the maximum possible', stating that the service user was 'at his limit' (EM 2).

A further three employers highlighted the need for service users to increase their levels of physical fitness to improve their chances of obtaining paid, competitive employment.

When asked how their mental health affected them on a day-to-day basis, service users' responses varied, with stating that it was a 'burden; and' 'stressful' (SU 3), and with others unable to describe how their mental health difficulty affected them on a day-to-day basis, responding to this question by stating their diagnosis.

Four MDT members stated that they believed that all service users could return to the workforce 'with support'; and one MDT member stated: 'It is difficult to go from doing nothing to paid employment' (MDT8).

The remaining MDT members answered this question very differently, stating that they did not think that all service users could return to the workforce, with one member saying: 'I would love to say yes but some just can't' (MDT4). Another member answered this question with an emphatic 'No', stating: 'With symptom severity and a long time out of the workforce some service users will never return to employment' (MDT5).

\section{Employment/vocational-related-issues}

Employers and MDT members were asked questions regarding their knowledge of the supports available in the community and from the Department of Employment Affairs and Social Protection to assist service users in returning to the workforce. Service users were asked questions relating to their current vocational activities and any concerns they might have regarding social welfare payments and benefits.

Employers were asked about their knowledge of supports available for people with a mental health difficulty to return to the workplace. Two employers (EMP1, EMP 3) stated that they were aware of supports, as directories of these services were available in their organisations.

EMP 5 stated that they had no knowledge of any supports available, apart from one employment specialist service in the west of the country. The remaining employers stated that they had no knowledge of supports available for people with a mental health difficulty to return to the workplace.

A specific question was asked regarding employers' knowledge of wage subsidy schemes which operate from the Department of Employment Affairs and Social Protection. Four employers stated that they had no knowledge of the Wage Subsidy Scheme, another employer claiming that they had heard of it in a previous role but had understood that this support was only for those with a physical disability.

Employers were also asked about their knowledge of the legislation regarding employing a person with a disability. Six employers responded that they had no knowledge regarding this legislation. EMP 8 responded 'probably we could know more', going on to state that they have much more knowledge regarding employing a 
person with a physical disability than a mental health disability and confirming that there is much more awareness of supports available for people with physical disabilities.

Service users voiced a variety of concerns about returning to the workforce ranging from 'not fit enough' (SU1) and 'not being able to cope' (SU2) to 'not fitting in' and 'letting people down (SU3).

SU 4 stated that they had concerns about not having 'enough experience', going on to say: 'You would need a good CV and education' (SU4).

Without any prompting, no service user identified any concerns or worries regarding social welfare payments/ benefits. With prompting, three service users (SU1, SU4, SU6) stated that they had concerns regarding their social welfare payments, saying: 'You might lose them then lose your job and your benefits cut' (SU4). SU6 stated that they would not like to lose their social welfare payment, as they 'mightn't get it back again'.

When asked for suggestions or changes that MDT members would implement in the Mental Health Services, to increase the opportunities for service users to return to the workforce, five MDT members recommended introducing more dedicated employment specialist roles, with MDT 6 stating: 'What is necessary is a core team solely to deal with that [returning to employment] and working with the IPS person' (MDT6).

MDT 4 cited the importance of early intervention with service users stating: 'That's the time to get them [service users] when they appear on the Unit (Adult Mental Health Unit) and not slip into the net of not going to work' (MDT4).

\section{Stigma surrounding mental health}

With regard to stigma and mental health, respondents were asked whether they had any concerns disclosing to an employer that they had a mental health difficulty. The results found that three service users had no concern disclosing that they had a mental health difficulty, with one service user stating: 'It is important to talk to an employer about your depression and explain so that they can understand where you are coming from' (SU4).

However, remaining participants stated that they would not be happy to disclose to an employer that they had a mental health difficulty, all citing a fear of not getting the job. Their concerns regarded being 'treated differently' (SU2), or a fear that the employer may 'not treat [them] fairly, side-line [them] or let [them] go' (SU3).

All MDT members interviewed stated that, in their opinion, a stigma surrounding mental health difficulties was still present today:' Absolutely, very much so' (MDT5).

MDT respondents also highlighted the stereotypical portrayal of the person with a mental health difficulty in the media as an issue that needs to be addressed in overcoming this stigma.

Another recommended empowering service users to feel confident going out into the workforce making them aware that 'They are entitled to work like any other person and cannot be discriminated against' (MDT2).

Responses from employers highlighted an understanding of that sense of stigma and a necessity to provide extra support for individuals. Three employers highlighted the support provided by an employment specialist as important in this regard: 'Just a person to contact ... a person to speak to in case something happened, and we didn't know how to deal with it' (EMP 2).

\section{DISCUSSION}

Support for those with a mental health difficulty to return to employment continues to be an unmet need for those with a mental health difficulty (Cullen, et al., 2017; Mental Health Reform, 2018). The findings from this research confirmed that mental health clients were apprehensive about their first step back into the workforce, preferring to avail of work experience/work trial opportunities over paid competitive employment as their first choice in their return-to-work journey. While personal factors play a role here, so too does the perception that service users have of employment and the potential issues they may face in integration and performance at work. It is also important for people with mental health difficulties to have knowledge of workplace protections for those who have a disclosed disability. No MDT member in this current study stated that a service user should go straight back into paid competitive employment without a form of support. This concurs with findings in existing literature, whereby mental health treatment teams may fear that paid competitive employment can be stressful and unhelpful to some clients (Boardman and Rinaldi, 2013; Krupa, et al., 2009). This concurs with findings from previous research (Biggs, et al., 2010; Moore, et al., 2017). The findings therefore highlight the importance of programmes such as IPS in providing dual support, not only for employees but for employers, in ensuring a successful transition to employment. The efficacy of the IPS model of supported employment has been demonstrated in the literature (Essen, 2012; 
Drake Bond, 2011). However, the system as currently available in Ireland is regionally limited and therefore requires greater national coordination and investment to support a broader cohort of employers.

The IPS Model is premised on its 'place and then train' approach for all clients. Employers highlighted issues such as a lack of training, insufficient current skillsets, and low self-esteem among some of those employed. Our study highlights difficulties that have emerged for employers regarding the 'train and place' aspect of the IPS model and the ethos of the IPS model that the client does not need to be 'job ready'. Difficulties were noted with the need for excessive supervision and the costs involved, particularly for small businesses and sole traders. Hand et al. (2006) noted the challenges for smaller employers. Our findings concur that while challenging, issues are not insurmountable. However, it is important that employers are made aware of such issues prior to involvement in the IPS programme, such that they can allow for the additional time or resources required for a successful integration. Through IPS the employment specialist can advise on suitable workplace accommodations and supports, such as allowing for increased personal space, being closer to an exit or working to an amended schedule.

A recurring theme emerging from this research was the perceived lack of supports available when employing a person with a mental health difficulty. Supports such as the Disability Allowance Employment Disregard, Adaptation Grants and Wage Subsidy Schemes are available from the Department of Employment Affairs and Social Protection in Ireland, to assist in returning to the workforce. This research study has highlighted employers' lack of knowledge about supports that are available and particularly their lack of knowledge regarding the Wage Subsidy Scheme. It has also noted that employers have little to no knowledge of the legislation that is in place regarding employing a person with a disability. While IPS has demonstrated some success to date, a recommendation from this research would be to incentivise employers to engage in the 'place and then train' IPS approach, by providing grants to defer these costs, in the same way as Adaptation Grants are made available to employers when hiring a person with a physical disability. However, no incentives are made available to employers hiring a person with a mental health difficulty under the IPS model. Employers are expected to adopt a 'place and then train' approach with service users and the cost of this training, support and extra supervision is borne wholly by the employer.

Stigma and the mental health client have been extensively researched and documented. The literature highlights the need to better understand the requirements and accommodations of workers with mental health disabilities (Cavanagh et al., 2017). Responses obtained from employers in this study strongly suggest that they are willing to hire a person with a mental health difficulty with the caveat that they (the service users) can do the work and that supports are in place to assist both parties, should any issues arise. This is in keeping with previous research, which suggests that employers were willing to hire a person with a mental health difficulty, provided that it was cost-effective and came with guidance (Shankar, et al., 2014). Our findings therefore have important implications for understanding willingness to disclose mental health issues to an employer, and the potential benefits of such disclosure to both the client and employer. Half the service users interviewed were not inclined to disclose that they had a mental health difficulty to an employer, yet our study shows that employers were willing to employ a person with a mental health difficulty, provided that the person was able to do the job. Fear of not getting the job, being treated differently, being side-lined or being let go were all fears/worries cited by the service users regarding the disclosure of their mental health difficulties to potential employers. Employers and employment support specialists may therefore need to consider how to overcome this issue with those who have a mental health condition, by highlighting previous employee experiences and outlining positive experiences that others have had.

Further research is needed to understand how employers can support the transition from supported employment to independent employment, given that the number of respondents in our study who had made that transition was very low. This would complement the work of DeTore et al. (2019), which considered psychosocial factors. More research is also required on the extent to which co-workers play a role in the long-term integration process of individuals with mental health issues, to determine what possible training interventions may work best in this regard. A range of alternatives to the IPS model should also be developed in conjunction with input from employers, for example, the provision of a supported suite of vocational options such as training, upskilling, work experiences and volunteering roles in keeping with a recovery focused mental health service and the requirements of the current labour market.

The present study has captured the voices of members of a very niche group, who have been part of this targeted employability support programme. However, given the focus on one region, and a limited number of participants, the generalisability of the study is limited. The methodological design also has some limitations, in that we were unable to address some issues directly with the service users, due to their underlying vulnerabilities. 


\section{CONCLUSION}

In a recent report compiled by KPMG Australia and Mental Health Australia (2018), the economic benefits and return on investments in targeted, practical, evidence-based interventions such as IPS employment programmes were found to produce 'win-win' scenarios that could improve workplace participation by $30 \%$ among this group. However, the role of employers is crucially important, as can be seen from our findings. The provision of supports at macro level will only deliver results where employers concurrently support the IPS goals at organisation level. A top-down approach is insufficient, as line managers and other employees are also integral to the success of individual placements. Employers therefore need to encourage awareness of mental health, at all levels of their organisations. As illustrated by Cavanagh et al. (2107), supervisory supports are essential to successful transitions into employment. Recognising that employers will face challenges in facilitating employees with a mental health issue in accessing the labour market is an important first step towards institutional change, where provisions that are available to support employers are made more widespread. Based on the findings from this research, we recommend enhanced resourcing for the provision of supported employment services throughout Ireland, so that services are more easily accessible for employers in all regions. The Department of Employment Affairs and Social Protection can also facilitate greater awareness of these supports to inform potential employers about such programmes. The impact of COVID-19 has been identified as a factor likely to contribute to increased levels of mental health concerns, Maulik et al. (2020) have argued that coordinated action needs to be taken to support civil societies and employers in addressing the increased burden of mental illness.

\section{REFERENCES}

Amnesty International (2013). Employment and Mental Health: A Briefing Paper. https://www.amnesty.ie/ employment-mental-health-briefing-paper/

Batinic, B., Selenko, E., Stiglbauer, B. and Paul, K.I. (2010). 'Are workers in high-status jobs healthier than other? Assessing Jahoda's latent benefits of employment in two working populations'. Work \& Stress, 24: 1, 73-87.

Bell, E. and Bryman, A. (2007). 'The ethics of management research: An exploratory content analysis. British Journal of Management, 18: 1, 63-77.

Bell, M.D., Choi, J. and Lysaker, P. (2007). 'Psychological interventions to improve work outcomes for people with psychiatric disabilities'. Journal of the Norwegian Psychological Association, 44, 2-14.

Beland, L.P., Brodeur, A., Mikola, D. and Wright, T. (2020). The Short-term Economic Consequences of COVID-19: Occupation Tasks and Mental Health in Canada. and Mental Health in Canada. IZA Discussion Paper No. 13254, Available at SSRN: https://ssrn.com/abstract=3602430

Biggs, D., Hovey, N., Tyson, P.J. and MacDonald, S. (2010). 'Employer and employment agency attitudes towards employing individuals with mental health needs'. Journal of Mental Health, 19: 6, 509-516.

Bilsker, D., Gilbert, M., Myette, T.L. and Stewart-Patterson, C. (2004). Depression \& Work Function: Bridging the Gap Between Mental Health Care \& the Workplace. Depression in the Workplace Collaborative. 2004 Mental Health Evaluation and Community Consultation Unit, Vancouver

Boardman, J. and Rinaldi, M. (2013). 'Difficulties in implementing supported employment for people with severe mental health problems'. The British Journal of Psychiatry, 203, 247-249.

Boardman, J. and Rinaldi, M. (2013). Difficulties in implementing supported employment for people with severe mental health problems'. The British Journal of Psychiatry, 203, 247-249.

Bond, G. and Kukla, M. (2011). 'Impact of follow-along support on job tenure in the individual placement and support model'. Journal of Nervous and Mental Disease, 199: 3, 150-155.

Bond, G. and Kukla, M. (2011). The impact of follow-along support on job tenure in the individual placement and support model. Journal of Nervous and Mental Disease, 199: 3), 150-155.

Bond, G.R. and Drake, R.E. (2014). 'Making the case for IPS supported employment'. Administration and Policy in Mental Health and Mental Health Services Research, 41: 1, 69-73.

Braun, V. and Clarke, V. (2006). 'Using thematic analysis in psychology'. Qualitative Research in Psychology, 3: 2, 77-101.

Campbell, K., Bond, G.R., Drake, R.E., McHugo, G.J. and Xie, H., 2010. Client predictors of employment outcomes 
in high-fidelity supported employment: a regression analysis. The Journal of nervous and mental disease, 198(8), pp.556-563

Campbell, K., Bond, G.R. and Drake, R.E. (2011). 'Who benefits from supported Employment: A meta analytic study'. Schizphrenia Bulletin, 37: 2, 370-380.

Carroll, C., Rick, J., Pilgrim, H., Cameron, J. and Hillage, J. (2010). 'Workplace involvement improves return to work rates among employees with back pain on long-term sick leave: A systematic review of the effectiveness and cost-effectiveness of interventions. Disability and Rehabilitation, 32: 8, 607-621.

Cassell, J. (1982). 'Harms, benefits, wrongs, and rights in fieldwork, in: J. Sieber (ed.), The Ethics of Social Research: Fieldwork, Regulation and Publication, New York: Springer-Verlag.

Cassidy, T and Wright, L. (2008). 'Graduate employment status and health: A longitudinal analysis of the transition from student', Social Psychology and Education, 11, 181-191.

Cavanagh, J., Bartram, T., Meacham, H., Bigby, C., Oakman, J. and Fossey, E. (2017). 'Supporting workers with disabilities: A scoping review of the role of human resource management in contemporary organisations'. Asia Pacific Journal of Human Resources, 55: 1, 6-43.

CIPD (2018). Supporting mental health at work. https://www.cipd.ie/news-resources/practical-guidance/guides/ supporting-mental-health-work

CSO (2017). 'Press Statement Census 2016 Results Profile 9 - Health, Disability and Carers'. https://www. cso.ie/en/csolatestnews/pressreleases/2017pressreleases/pressstatementcensus2016resultsprofile9healthdisabilityandcarers/

CSO (2019). Monthly Unemployment Rate May 2019. https://www.cso.ie/en/releasesandpublications/er/mue/ monthlyunemploymentmay2019/

Cullen, K., McDaid, D., Wynne, R., Matosevic, T. and La Park, A., (2017). Evidence Review to Inform the Parameters for a Refresh of A Vision for Change (AVFC), Dublin: The London School of Economics and Political Science; Work Research Centre.

De Lorenzo, M.S. (2013). 'Employee mental illness: Managing the hidden epidemic'. Employ Respons Rights Journal, 25, 219-238.

Department of Employment Affairs and Social Protection (2018). Wage Subsidy Scheme. https://www.welfare.ie/en/ Pages/Wage-Subsidy-Scheme_holder_3176.aspx

DeTore, N.R., Hintz, K., Khare, C. and Mueser, K.T. (2019). 'Disclosure of mental illness to prospective employers: Clinical, psychosocial, and work correlates in persons receiving supported employment'. Psychiatry Research, 273, 312-317.

Donnelly, C. (2017). Public attitudes toward disclosing mental health conditions. Social Work in Mental Health, 15: $5,588-599$.

Drake, R.E. (1998). 'A brief history of the individual placement and support model'. Psychiatric Rehabilitation Journal, 22: 1, 3-8.

Drake, R.E. and Bond, G.R. (2011). IPS 'Support employment: A 20-year update'. American Journal of Psychiatric Rehabilitation, 14, 155-164.

Drake, R.E., Bond, G.R., Thornicroft, G., Knapp, M. and Goldman, H.H., (2012). 'Mental health disability: An international perspective'. Journal of Disability Policy Studies, 23: 2, 110-120.

Easterby-Smith, M., Thorpe, R. and Jackson, P.R. (2015). Management and Business Research (5th ed.), London: Sage.

Edmondson, A.C. and McManus, S.E. (2007). 'methodological fit in management field research'. Academy of Management Review, 32: 4, 1155-1179.

Essen, C. (2012). 'Does Individual Placement and Support really "reflect client goals?. Journal of Psychiatric and Mental Health Nursing, 19, 231-240.

European Union of Supported Employment (2010). European Union of Supported Employment Toolkit, Dundee: European Union of Supported Employment.

Fischer, C.T. (2006). 'Introduction', in C.T. Fischer (ed.), Qualitative Research Methods for Psychologists, London: Elsevier.

Gaffey, K. and Evans, D. (2016). 'Knowledge and attitudes of Irish mental health professionals to the concept of recovery from mental illness - five years later'. Journal of Psychiatric and Mental Health Nursing, 23, 387-398.

Hampson, M., Hicks, R. and Watt, B. (2016). 'Understanding the employment barriers and support needs of people living with psychosis'. The Qualitative Report, 21: 5, 864-880. 
Hand, C. and Tryssenaar, J. (2006). 'Small business employers' views on hiring individuals with mental illness'. Psychiatric Rehabilitation Journal, 29: 3, 166-173.

Henderson, C., Williams, P., Little, K. and Thornicroft, G. (2013). 'Mental health problems in the workplace: Changes in employers' knowledge, attitudes and practices in England 2006-2010. The British Journal of Psychiatry, 202: s55, s70-s76.

Hodgson, M.H., McCulloch, H.P. and Fox, K.R. (2011). 'The experiences of people with severe and enduring mental illness engaged in a physical activity programme integrated into the mental health service'. Mental Health and Physical Activity, 4: 1, 22-29.

HSE (2006). A Vision for Change, Dublin: THE STATIONERY OFFICE.

Khalema, N.E. and Shankar, J. (2014). 'Perspectives on employment integration, mental illness and disability, and workplace health'. Advances in Public Health, 2014: 1, 1-7.

Knapp, M., Andrew, A., McDaid, D., lemmi, V., McCrone, P., Park, A.L., Parsonage, M., Boardman, J. and Shepherd, G. (2014). Making the Business Case for Effective Interventions for People with Schizophrenia and Psychosis, London: Dept of Health.

Krupa, T., Kirsh, B., Cockburn, L. and Gewurtz, R. (2009). 'Understanding the stigma of mental illness in employment.' Work, 33, 413-425.

Leach, L.S. and Butterworth, P. (2012). 'Psychiatry research'. The Effect of Early Onset Common Mental Disorders on Educational Attainment in Australia, 199: 1, 51-57.

Luciano, A., Bond, G.R. and Drake, R.E. (2014). 'Does employment alter the course and outcome of schizophrenia and other severe mental illnesses? A systematic review of longitudinal research'. Schizophrenia Research, $159,312-321$.

McCann, T.V. and Clark, E. (2005). 'Using unstructured interviews with participants who have schizophrenia (interviewing)'. Nurse Researcher, 13: 1, 7-12.

Maulik, P.K., Thornicroft, G., Saxena, S. (2020). 'Roadmap to strengthen global mental health systems to tackle the impact of the COVID-19 pandemic'. International Journal of Mental Health Systems, 14: 1, 1-13.

McAnaney, D. and Wynne, R. (2017). International Good Practice in Vocational Rehabilitation: Lessons for Ireland. Dublin, Ireland: National Disability Authority.

McKee-Ryan, F. and Harvey, J. (2011). 'I have a job, but...': A review of underemployment'. Journal of Management 37: 4, 962-996.

McClelland, R., Webb, M. and Mock, G. (2000). 'Mental Health Services in Ireland'. International Journal of Law and Psychiatry, 23: 3-4, 309-328.

Mental Health Reform (2015). A Vision for Change Nine Years on: A Coalition Analysis of Progress, Dublin: Mental Health Reform.

Mental Health Reform (2018). Steps into work: Integrating Employment and Mental Health Supports Project Final Report, Dublin: Mental Health Reform.

Meuser, K.T., Drake, R.E. and Bond, G.R. (2016). 'Recent advances in supported employment for people with serious mental illness'. Current Opinion in Psychiatry, 29: 3, 196-201.

Mojtabai, R., Stuart, E.A., Hwang, I., Eaton, W.W., Sampson, N. and Kessler, R.C., (2015). 'Long-term effects of mental disorders on educational attainment in the National Comorbidity Survey ten-year follow-up'. Social Psychiatry and Psychiatric Epidemiology, 50: 10, 1577-1591.

Moore, K., McDonald, P. and Bartlett, J. (2017). 'The social legitimacy of disability inclusive human resource practices: the case of a large retail organisation'. Human Resource Management Journal, 27: 4, 514-529.

O’Day, B., Kleinman, R., Fischer, B., Morris, E. and Blyler, C., (2017). 'Preventing Unemployment and disability benefit receipt among people with mental illness: Evidence review and policy significance'. Psychiatric Rehabilitation Journal, 40: 2, 123-152.

Prior, S., Maciver, D., Forsyth, K., Walsh, M., Meiklejohn, A. and Irvine, L., (2013). 'Readiness for employment: perceptions of mental health service users'. Community Mental Health Journal, 49, 658-667.

Rüsch, N., Rose, C., Holzhausen, F., Mulfinger, N., Krumm, S., Corrigan, P.W., Willmund, G.D. and Zimmermann, P.,. (2017). 'Attitudes towards disclosing a mental illness among German soldiers and their comrades'. Psychiatry Research, 258, 200-206.

Schultze, U. and Avital, M. (2011). 'Designing interviews to generate rich data for information systems research'. Information and Organisation, 21: 1, 1-16.

See Change (2016). About See Change. https://seechange.ie/mission-statement/ 
See Change (2017). www.seechange.ie. https://seechange.ie/wp-content/uploads/2018/02/See-Change-What-isStigma-A5-brochure-HR.pdf

Shankar, J., Liu, L., Nicholas, D., Warren, S., Lai, D., Tan, S., Zulla, R., Couture, J. and Sears, A., (2014). 'Employers' perspectives on hiring and accommodating workers with mental illness'. Sage Open, 3: 2, 1-13.

Shefer, G., Henderson, C., Frost-Gaskin, M. and Pacitti, R. (2016). 'Only making things worse: A qualitative study of the impact of wrongly removing disability benefits from people with mental illness'. Community Mental Health Journal, 52, 834-841.

Sveinsdottir, V., Løvvik, C., Fyhn, T., Monstad, K., Ludvigsen, K., Øverland, S. and Reme, S.E., (2014). Protocol for the effect evaluation of Individual Placement and Support (IPS): A randomized controlled multicenter trial of IPS versus treatment as usual for patients with moderate to severe mental illness in Norway'. BMC Psychiatry, 14, 1-10.

The Equality Authority (2011). Equality and Mental Health: What the Law Means for Your Workplace, Dublin: The Equality Authority.

Trade Union Congress Report (2017). Mental Health in the Workplace. https://www.tuc.org.uk/sites/default/files/ Mental_Health_and_Employment.pdf

Villotti, P., Corbière, M., Fossey, E., Fraccaroli, F., Lecomte, T. and Harvey, C., (2017). 'Workplace accommodations and natural supports for employees with severe mental illness in social businesses: An international comparison'. Community Mental Health Journal, 53, 864-870.

Watson, D., Banks, J. and Lyons, S. (2015). Educational and Employment Experiences of People with a Disability in Ireland: An Analysis of the National Disability Survey 2015, Dublin: National Disability Authority.

Wilson, C. (2014). Interview Techniques for UX Practitioners (1st ed.), London: Elsevier. 